
\title{
Research Suate \\ Co-digestion of hybrid Pennisetum and peanut shell after adding TiO2 nanoparticles: Focusing on the synergistic effects on methane production
}

HongMei Zhao (D 1048354649@qq.com)

Yunnan Agriculture University: Yunnan Agricultural University https://orcid.org/0000-0003-0649-4972

Meng Jiang

Yunnan Agriculture University

\section{Research Article}

Keywords: anaerobic fermentation, methane production, TiO2 nanoparticles, Hybrid Pennisetum, peanut shell

Posted Date: May 7th, 2021

DOI: https://doi.org/10.21203/rs.3.rs-461356/v1

License: (c) (i) This work is licensed under a Creative Commons Attribution 4.0 International License.

Read Full License 
Co-digestion of hybrid Pennisetum and peanut shell after adding $\mathrm{TiO}_{2}$ nanoparticles: Focusing on the synergistic effects on methane production

Hongmei Zhao ${ }^{\mathrm{a}, \mathrm{b}}$, Jiang Meng ${ }^{\mathrm{b}}$

${ }^{a}$ Key Laboratory of Medicinal Chemistry for Natural Resources, Chemistry School of Chemical Science and Technology, Yunnan University, Kunming, 650091, P. R. China

${ }^{\mathrm{b}}$ School of Science, Yunnan Agricultural University, Kunming,650201, China

Abstract Anaerobic digestion is a widely accepted method to treat wastes such as peanut shell. The energy and nutrients are simultaneously recovered by this method. The objective of this study was to elucidate the effect of $\mathrm{TiO}_{2}$ nanoparticles in co-digestion of hybrid Pennisetum and peanut shell under mesophilic conditions. The results demonstrated the met hane $\left(\mathrm{CH}_{4}\right)$ production was improved by adding the $\mathrm{TiO}_{2}$ nanoparticles. The cumulative ga $\mathrm{s}$ production is best (up to $11,133.3 \mathrm{~mL}$ ) by adding $0.15 \%$ nano- $\mathrm{TiO}_{2}$ particles. The micro bial community analysis showed that Methanobacterium and Methanosarcina were enriched in the presence of $\mathrm{TiO}_{2}$ nanoparticles indicating that $\mathrm{TiO}_{2}$ can improve $\mathrm{CH}_{4}$ production by stimulating the growth of methanogens.

Key words: anaerobic fermentation; methane production; $\mathrm{TiO}_{2}$ nanoparticles; Hybrid Pennisetum; peanut shell 


\section{Introduction}

The total annual output of peanuts in China is 5 million tons. Peanut shells (PS) are food waste, and food waste constitutes $30-50 \%$ of municipal solid waste ${ }^{[1-2]}$. Approximately 60 million tons of food waste was produced last year in China alone. Food waste production is expected to keep increasing while maintaining social/economic growth as well as population growth.

Hybrid Pennisetum (HP) is herbaceous plant with great energetic potential. It has a high biological yield, strong regeneration ability, and multiple rounds of harvest ${ }^{[3-4]}$. Many researchers have focused on methane production from anaerobic fermentation of hybrid Pennisetum. However, Pennisetum is not fully utilized when used as a carbon source. Therefore, significant effort is needed to handle ever-increasing peanut shell waste and use it to produce biogas via Pennisetum.

Aerobic digestion has been developed and is well recognized as a promising tool for waste stabilization and energy recovery in the form of biogas. It has two processes: wet anaerobic digestion and dry anaerobic digestion. The total solid of wet anaerobic digestion system is less than $15 \%$, and the total solid of dry anaerobic digestion system is higher than $15 \%{ }^{[5-6]}$. Dry anaerobic digestion (DAD) is increasingly popular. This requires less water, and it does not cause more pollution than a wet digestion system ${ }^{[7-9]}$. In addition, co-digestion can greatly improve specific methane yields and methane production rates versus mono-digestion because of the superior nutrient availability and synergistic microbiomes.

Nanoparticles offer unique physiochemical properties and widespread applications ${ }^{[10]}$. Their effects on the environment have been investigated, but most studies focused on soil and wastewater toxicity ${ }^{[11-12]}$. The effect of nanomaterials on wastewater treatment has been reported ${ }^{[13-15]}$. The adsorption of activated sludge was reported to be the main mechanism of nanoparticles. Nevertheless, the effects of metal oxide nanoparticles (such as $\mathrm{TiO}_{2}$ nanoparticles) on anaerobic digestion for HP and PS are rarely investigated. $\mathrm{TiO}_{2}$ nanoparticles have no significant toxicity on the viability of bacterial cells and show no inhibitory effects on waste-activated sludge digestion.

In this study, dry anaerobic experiments were conducted under mesophilic conditions with different mixing ratios of HP and PS. The purpose was to investigate methane production with different ratios of HP and PS, investigate the effects of five dosages of the $\mathrm{TiO}_{2}$ nanoparticles on methane yield, and assess the influences of $\mathrm{TiO}_{2}$ nanoparticles on flora.

\section{Materials and Methods}




\subsection{Feedstock and inoculum}

The surface part of hybrid Pennisetum used here was from the experimental farm of Yunnan Agricultural University, Kunming, Yunnan Province. The samples were cut into $2-3 \mathrm{~cm}$. The dehydrated sludge was taken from the fifth water purification plant in Kunming, Yunnan Province, and appeared brown. The total solids (TS) content was $15.46 \%$, and the volatile solid (VS) content was $41.54 \%$.

\subsection{Nanoparticles synthesis}

Nano- $\mathrm{TiO}_{2}$ powder was synthesized according to a reported route ${ }^{[16]}$. Here, $0.1600 \mathrm{~g}(0.84 \mathrm{mmol})$ of dopamine (3,4-dihydroxy- $\beta$-phenylethylamine) and $30 \mathrm{~mL}$ of benzyl alcohol were added to an Erlenmeyer flask and stirred vigorously for $20 \mathrm{~min}$. We then added $1.5 \mathrm{~mL}$ of $\mathrm{TiCl}_{4}$ dropwise. This was stirred vigorously at room temperature for $2 \mathrm{~h}$. The temperature was then increased to $80^{\circ} \mathrm{C}$, and the mixture was transferred to a polytetrafluoroethylene reactor at $80^{\circ} \mathrm{C}$ for 3 days. After cooling, the resulting red-brown mixture was centrifuged, the supernatant was decanted, and the precipitate was washed three times with chloroform and dried at $60^{\circ} \mathrm{C}$ to obtain a large amount of dark red nano- $\mathrm{TiO}_{2}$ powder.

\subsection{DNA extraction and PCR amplification}

DNA extraction of different digestion period samples was detected by a MIO-BIO Power Soil DNA Isolation Kit. The remaining steps for DNA extraction were performed via the DNA isolation kit protocol. Subsequently, the V4-V5 variable region of the bacterial 16S rRNA gene was amplified using primers $515 \mathrm{~F}$ and $926 \mathrm{R}$ through polymerase chain reactions (PCRs). PCR was performed in a $10 \mu \mathrm{L}$ volume containing $1 \times$ PCR buffer, $1 \mu \mathrm{L}$ dNTPs, $1 \mu \mathrm{L}$ primer, 1 unit taq DNA polymerase, and 5-50 ng template DNA under the two cycling conditions: Bacteria had pre-denaturation at $94^{\circ} \mathrm{C}$ for $2 \mathrm{~min}, 22$ cycles of denaturation at $94^{\circ} \mathrm{C}$ for $30 \mathrm{~s}$, annealing at $55^{\circ} \mathrm{C}$ for $30 \mathrm{~s}$ or $50^{\circ} \mathrm{C}$ for $30 \mathrm{~s}$, extension at $72^{\circ} \mathrm{C}$ for $30 \mathrm{~s}$, and a final extension at $72^{\circ} \mathrm{C}$ for $5 \mathrm{~min}$. Archaea had pre-denaturation at $94^{\circ} \mathrm{C}$ for $2 \mathrm{~min}, 30$ cycles of denaturation at $94^{\circ} \mathrm{C}$ for $30 \mathrm{~s}$, annealing at $50^{\circ} \mathrm{C}$ for $30 \mathrm{~s}$, extension at $72^{\circ} \mathrm{C}$ for $30 \mathrm{~s}$, and a final extension at $72^{\circ} \mathrm{C}$ for $5 \mathrm{~min}$. Finally, the PCR products were tested through high-throughput sequencing using the Illumina Miseq 2x300bp platform.

\subsection{Anaerobic digestion tests}

\subsubsection{Experimental set-up}

The digestion device consists of a $1 \mathrm{~L}$ reaction bottle, gas bottle, water bottle, and constant- 
temperature water bath. According to the experimental design, different ratios of substrates and $\mathrm{TiO}_{2}$ nanoparticles were added to the reactors. All rectors were incubated at $37\left( \pm 1^{\circ} \mathrm{C}\right)$.

\subsubsection{Feedstock}

The carbon to nitrogen ratio $(\mathrm{C} / \mathrm{N})$ plays an important role in dry $\mathrm{AD}$. If the $\mathrm{C} / \mathrm{N}$ is higher, then the gas yield may be lower. The methanogenic bacteria will be toxic if the $\mathrm{C} / \mathrm{N}$ is lower. According to Weiland and Richa, a $\mathrm{C} / \mathrm{N}$ ratio in the range of $20 \%-30 \%$ is the best. The $\mathrm{C} / \mathrm{N}$ ratio of hybrid Pennisetum is 31.15 (C $47.35 \%$ and $\mathrm{N} 1.52 \%$ ). The $\mathrm{C} / \mathrm{N}$ of peanut shell was also measured (Table 1). The $\mathrm{C} / \mathrm{N}$ ratio is 25 . We choose the hybrid Pennisetum and peanut shell as feedstocks.

Table 1. Analysis of the content of HP and PS elements.

\begin{tabular}{lcccc}
\hline \multirow{2}{*}{ Sample } & \multicolumn{4}{c}{ The content of elements } \\
\cline { 2 - 5 } & $\mathrm{C}$ & $\mathrm{H}$ & $\mathrm{N}$ & 元素 C/N \\
\hline PS & $60.60 \%$ & $5.90 \%$ & $2.40 \%$ & 25.25 \\
HP & $47.35 \%$ & $5.89 \%$ & $1.52 \%$ & 31.15 \\
\hline
\end{tabular}

\subsubsection{Experimental design}

The digestion process contains two steps. First, to determine the best ratio, the HP:PS mixing ratios were selected as 0:4, 1:3, 2:2, 3:1, and 4:0. Each sample group was set up in triplicates. Second, different quality scores of $\mathrm{TiO}_{2}$ nanoparticles were added to the reactors under the best ratio of HP:PS

\subsection{Analytical methods and characterization}

The volatile solids (VS) and the total solids (TS) were measured by standard methods ${ }^{[17-18]}$. Total carbon (TC) and total nitrogen (TN) were measured with an elemental analysis instrument (VARIOEL Ш, Germany). The 16s rRNA gene amplification and sequencing used NGS Illumina MiSeq 2 x 300 bp.

\section{Results and Discussion}

\subsection{Cumulative Methane production and daily methane yield}

Fig. 1 shows 40-day methane yields for different ratios of mixed feedstock and cumulative methane production. The $\mathrm{pH}$ values in reactors ranged from 6.5 to 7.5 because they were suitable for 
methanogenesis. The changing trend of daily methane yield and cumulative methane production are similar. However, the peak values of daily methane yield were different. The sample at 3:1 shows the highest daily methane yield on the 17th day and the highest value at $323 \mathrm{~mL}$. The highest cumulative production of the sample of $3: 1$ is $10,405 \mathrm{~mL}$. The results suggested that the best ratio of HP and PS is $3: 1$.

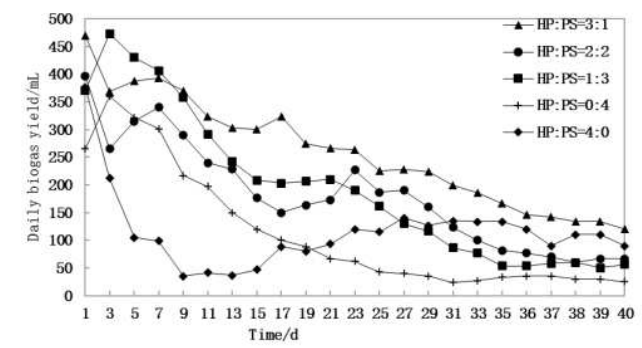

(a)

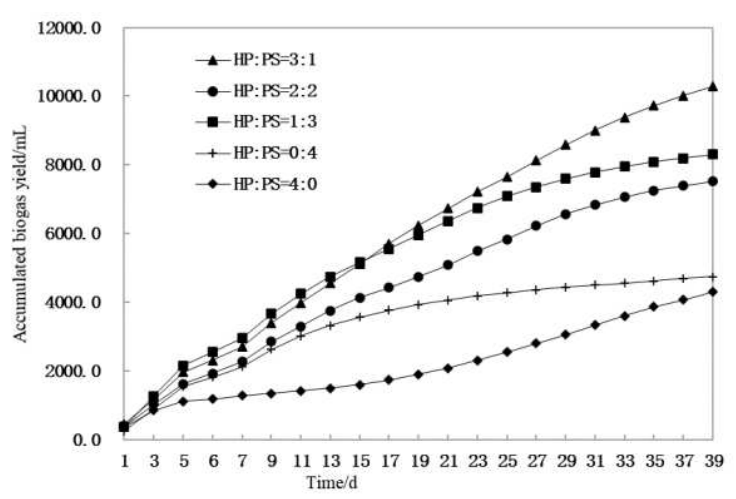

(b)

Fig. 1(a) Daily methane yield and (b) cumulative methane production.

\subsection{Impact of nano-TiO ${ }_{2}$ on methane production}

The effects of $\mathrm{TiO}_{2}$ nanoparticles on anaerobic digestion are shown in Fig. 2a. The $\mathrm{pH}$ values in the reactors also ranged from 6.5 to 7.5. Five sets of experiments with different amounts of $\mathrm{TiO}_{2}$ starting from 0 to $2 \%$ were performed. The results showed that the addition of $\mathrm{TiO}_{2}$ had an 
encouraging impact on methane production. Under $\mathrm{TiO}_{2}$ nanoparticles addition, the cumulative methane production increased significantly. When $0.15 \% \mathrm{TiO}_{2}$ was added, the cumulative methane production increased by $23.7 \%$. However, the methane production decreased when the concentration of $\mathrm{TiO}_{2}$ was $0.20 \%$. This indicated that the high concentration of $\mathrm{TiO}_{2} \mathrm{NPs}_{\text {s inhibits }}$ anaerobic digestion. The COD curves of different samples on anaerobic digestion are shown in Fig. $2 \mathrm{~b}$. The trend of COD decreased after 10 days. The nitrogen and carbon content is exhausted along with the aging of the microbial cells. Moreover, the COD removal efficiency was gradually increased, and the order of COD removal rates was blank $(57 \%)<0.05 \% \mathrm{TiO}_{2}(60 \%)<0.1 \% \mathrm{TiO}_{2}$ $(62 \%)<0.15 \% \mathrm{TiO}_{2}(65 \%)<0.2 \% \mathrm{TiO}_{2}(67 \%)$.



(a)

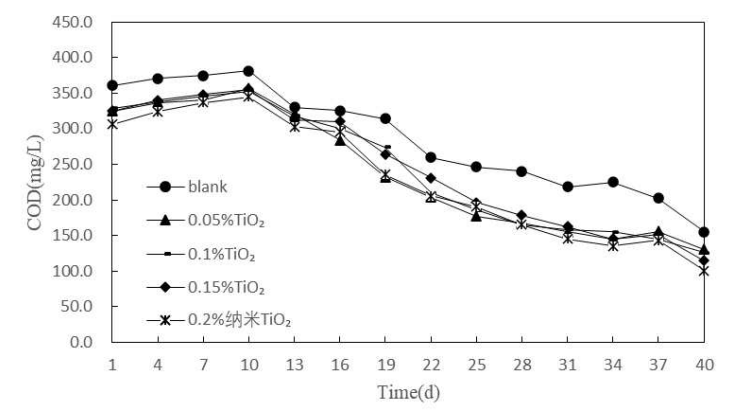

(b)

Fig. 2 The curves of cumulative methane production (a) and COD (b).

\subsection{Community diversity of archaea}

Archaeal community diversity of three samples with different fermentation periods is shown in Table 2. ACE and Chao1 indexes were used to compare the species richness, and the Shannon index was used to compare community diversity in different samples. The un-fermented (NF) samples had highest species richness with ACE and Chao 1 values of 57 and 58 followed by pre- 
fermented (FQ) samples (ACE of 57 and Chaol of 55) and middle-fermented (FM) samples with the lowest ACE (51) and Chao1 (50). The Shannon index also decreased in fermentation progresses.

Table 2. Comparison of species richness and community diversity estimators of the Archaeal communities in different samples.

\begin{tabular}{ccccccc}
\hline Sample & $\begin{array}{c}\text { Number of } \\
\text { sequences }\end{array}$ & OTUs & ACE & Chao 1 & $\begin{array}{c}\text { Shann } \\
\text { on }\end{array}$ & $\begin{array}{c}\text { Covera } \\
\text { ge }\end{array}$ \\
\hline NF & 10302 & 56 & 57 & 58 & 2.69 & $\begin{array}{c}99.98 \\
\%\end{array}$ \\
\hline FQ & 8284 & 52 & 57 & 55 & 2.52 & $\begin{array}{c}99.93 \\
\%\end{array}$ \\
FM & 18361 & 50 & 51 & 50 & 2.32 & $\begin{array}{c}99.99 \\
\%\end{array}$ \\
\hline
\end{tabular}

\subsection{Archaeal flora distribution of different samples}

As many as 14 archaeal flora were identified in the three different fermentation periods (Fig. $3)$. In the un-fermented period, the dominant archaea are Methanobacterium (35.20\%), Methanosaeta (19.37\%), Methanosporillum (18.00\%), and Methanobrevibacter (7.61\%). In prefermented period, the dominant archaea are Methanobacterium (52.90\%), Methanosaeta (14.18\%), Methanosporillum (7.69\%), Methanobrevibacter (9.11\%), and Metgabisarcina (7.40\%). In the middle-fermented period, the dominant archaea are Methanobacterium (40.40\%), Methanosaeta (20.47\%), Methanosporillum (23.06\%), and Metgabisarcina (5.23\%).

Therefore, the categories of major archaea genera were similar, but their relative abundances were different. The archaea of Methanobacterium and Metgabisarcina were enriched with the addition of $\mathrm{TiO}_{2}$ nanoparticles. These results indicate that $\mathrm{TiO}_{2}$ played an important and positive role in $\mathrm{CH}_{4}$ production.

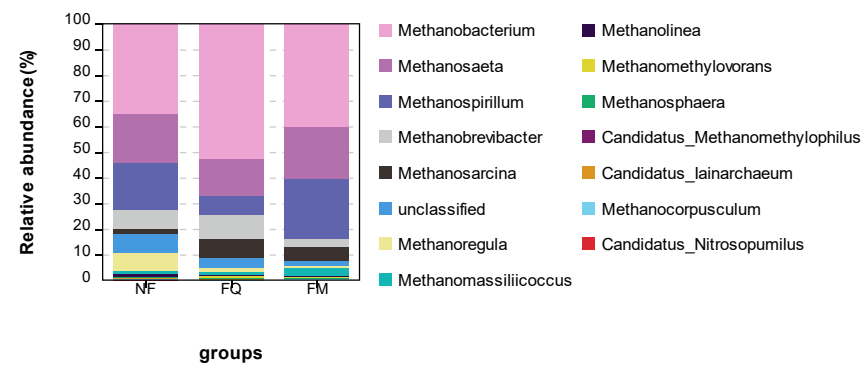

Fig. 3 Distribution of various stains at the genus level during anaerobic digestion.

\section{Conclusion}

This study indicated that the addition of $\mathrm{TiO}_{2}$ nanoparticles promoted methane production in the system of anaerobic co-digestion of hybrid Pennisetum and peanut shell. The archaea of Methanobacterium and Metgabisarcina can be enriched upon addition of $\mathrm{TiO}_{2}$ nanoparticles. This 
study expands our knowledge of the role of $\mathrm{TiO}_{2}$ nanoparticles in mixed dry anaerobic fermentation. In our future work, the effect of nanoparticles on fermentation will be further investigated, and biological flora will be studied in the fermentation process.

\section{Acknowledgments}

This work was supported by Engineering and Research Center for Industrial Biogas Technology of Yunnan Province University. The archaeal diversity analysis was performed using the Omicshare tools - a free online platform for data analysis (http://www.omicshare.com/tools.) We thank LetPub (www.letpub.com) for its linguistic assistance during the preparation of this manuscript.

\section{Funding Information}

The work received financial support from the Agricultural Joint Youth Project of Yunna Provincial Department of Science and Technology (2018FG001-102).

\section{Compliance with Ethical Standards}

Conflict of Interest The authors declare that they have no conflict of interest.

\section{References}

[1] Bi H B, Wang C X, Jiang X D, Jiang CL, Bao L, Lin Q Z. Thermodynamics, kinetics, gas emissions and artificial neural network modeling of co-pyrolysis of sewage sludge and peanut shell. Fuel 2021; 284:118988-12.

[2] Dahunsia SO, Oranusib S, Efeovbokhanc V.E. Optimization of pretreatment, process performance, mass and energy balance in the anaerobic digestion of Arachis hypogaea (Peanut) hull. Energy Conversion and Management 2017; 113:260-275.

[3] Kang X H, Zhang Y, Li Lianhua, Sun YM, Kong XY, Yuan Zhenhong. Enhanced methane production from anaerobic digestion of hybrid Pennisetum by selectively removing lignin with sodium chlorite[J]. Bioresource Technology 2020; 295:122289.

[4] Kumar R., Hu,F., Hubbell,C.A., Ragauskas,A.J., Wyman,C.E.,.Comparison of laboratory delignification methods, their selectivity, and impacts on physiochemical characteristics of cellulosic biomass. Bioresour. Technol 2013; 130:372-381.

[5] Forough M, Keikhosro K, Mohammad J T. Energy recovery from industrial crop wastes by dry anaerobic digestion: A review. Industrial Crops \& Products 2019;129: 673-687.

[6] Mirmohamadsadeghi S, Karimi K, Horváth I S. Improvement of solid-state biogas production 
from wood by concentrated phosphoric acid pretreatment. BioResour 2016; 11: 3230-3243.

[7] Augenstein D C, Wise D L, Wentworth R L, Cooney C L. Fuel gas recovery from controlled landfilling of Municipal waste. Res. Rec. Cons 1976; 2:103-117.

[8] Rodrigue J Z, Igkesuas, Castrillh L, Marafih E. Solid-state anaerobic digestion of unsorted municipal solid waste in a pilot-plant scale digester. Bioresource Terh-nolog 1998; 63:29-35.

[9] Juanga J P. 2005.Optimizing dry anaerobic digestion of organic fraction of municipal solid waste[A]. M. E. Thesis. Asian Institute of Technology[M]. Bank ok, Thailand.

[10] Roco, M C. The emergence and policy implications of converging new technologies integrated from the nanoscale. J. Nanopart. Res 2005;7(2-3):129-143.

[11] Ge Y, Schimel J P, Holden P A. Evidence for negative effects of $\mathrm{TiO}_{2}$ and $\mathrm{ZnO}$ nanoparticles on soil bacterial communities. Environ. Sci. Technol 2011; 45(4): 1659-1664.

[12] Limbach L K, Bereiter R, Mueller E, Krebs R, Gaelli R, Stark W J. Removal of oxide nanoparticles in a model wastewater treatment plant: influence of agglomeration and surfactants on clearing efficiency Environ Sci Technol. 2008; 42 (15): 5828-5833.

[13] Mu H, Chen Y G, Xiao N D. Effects of metal oxide nanoparticles $\left(\mathrm{TiO}_{2}, \mathrm{Al}_{2} \mathrm{O}_{3}, \mathrm{SiO}_{2}\right.$ and $\left.\mathrm{ZnO}\right)$ on waste activated sludge anaerobic digestion. Bioresource Technology 2011;102: 1030510311.

[14] Baraka M A, Anjum M, Kumar R, er al. Design of ternary $\mathrm{Ni}(\mathrm{OH})_{2} /$ grapheneoxide $/ \mathrm{TiO}_{2}$ nanocomposite for enhanced photocatalytic degradation of organic, microbial contaminants, and aerobic digestion of dairy wastewater. Journal of Cleaner Production 2020;258: 120588.

[15] Abdelsalam E, Samer M, Attia YA, Abdel-Hadi MA, Hassan HE, Badr Y. Comparison of nanoparticles effects on biogas and methane production from anaerobic digestion of cattle dung slurry. Renew Energy 2016; 87:592-598.

[16] Niederberger M, Garnweitner G, Krumeich F , et al. Tailoring the Surface and Solubility Properties of Nanocrystalline Titania by a Nonaqueous In Situ Functionalization Process[J]. Chemistry of Materials 2004;16(7): 1202-1208.

[17] APHA, AWWA, WEF, 2005. Standard Methods for the Examination of Water and Wastewater, twenty-first ed. American Public Health Association/American waterworks Association/water Environment Federation Washington DC, USA.

[18] Liu S G, Yang X, Yao X F. Impacts of ammonia nitrogen on autothermal thermophilic micro- 
aerobic digestion for sewage sludge treatment. Chemosphere 2018; 213:268-275. 
Figures

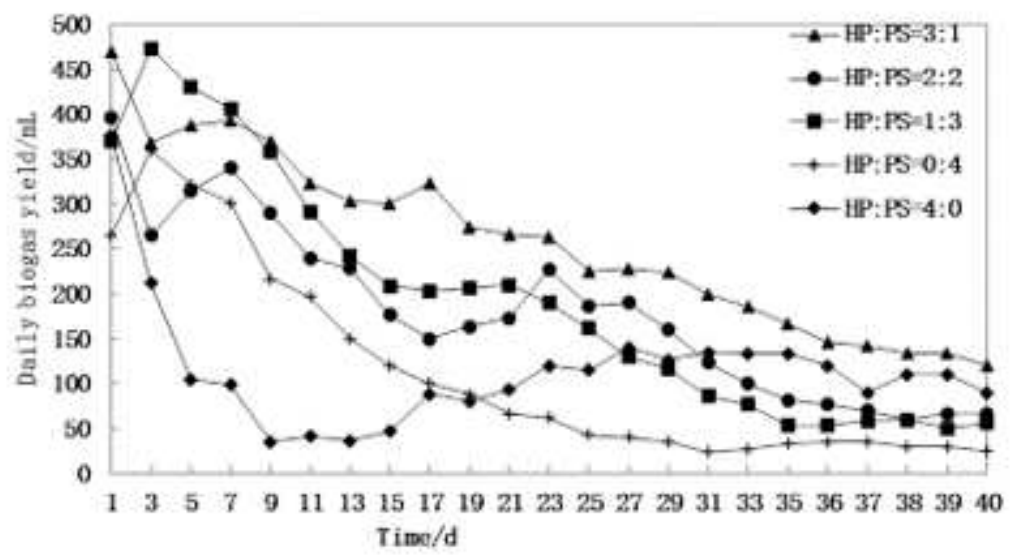

(a)

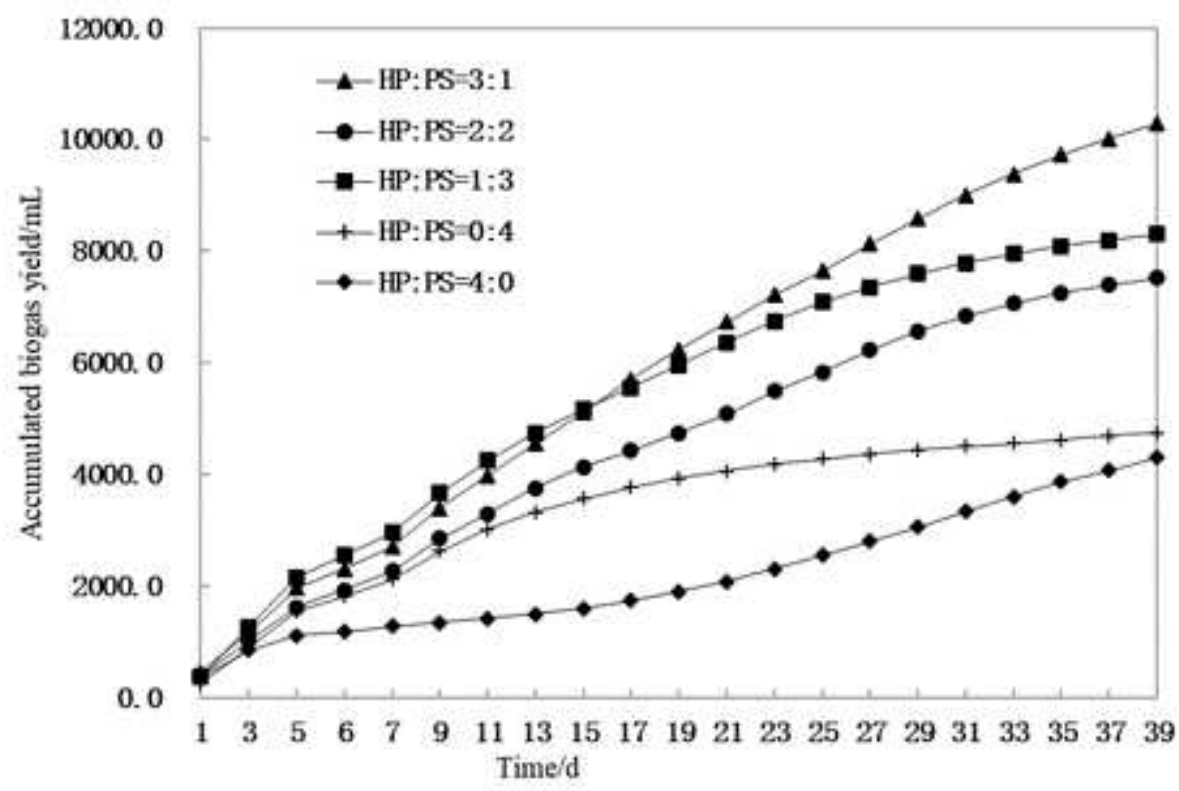

(b)

Figure 1

(a) Daily methane yield and (b) cumulative methane production. 


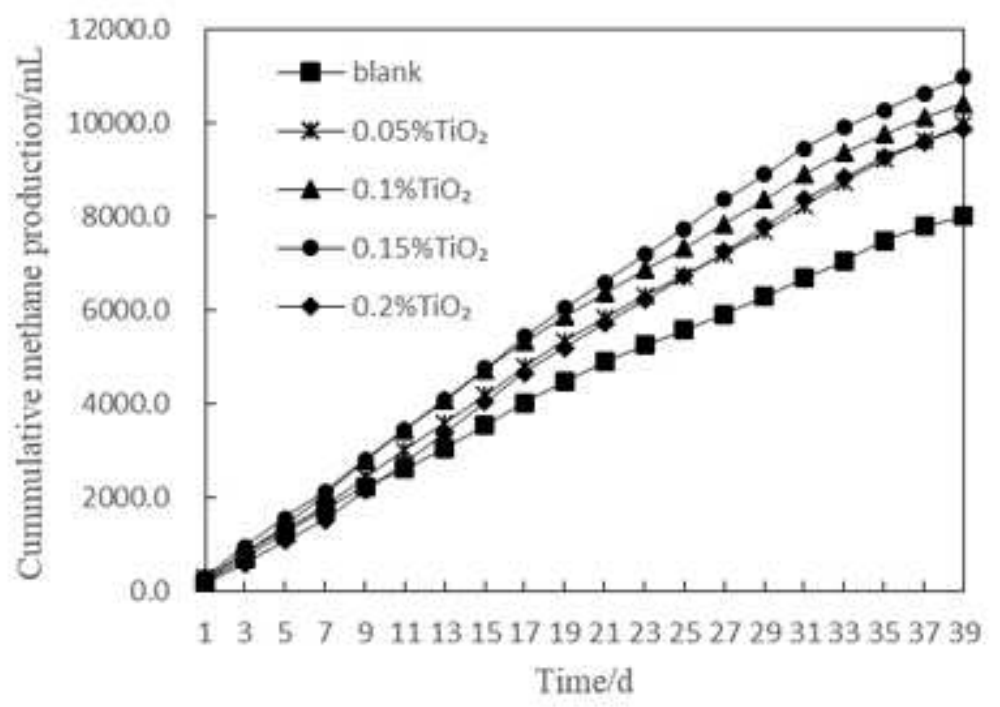

(a)

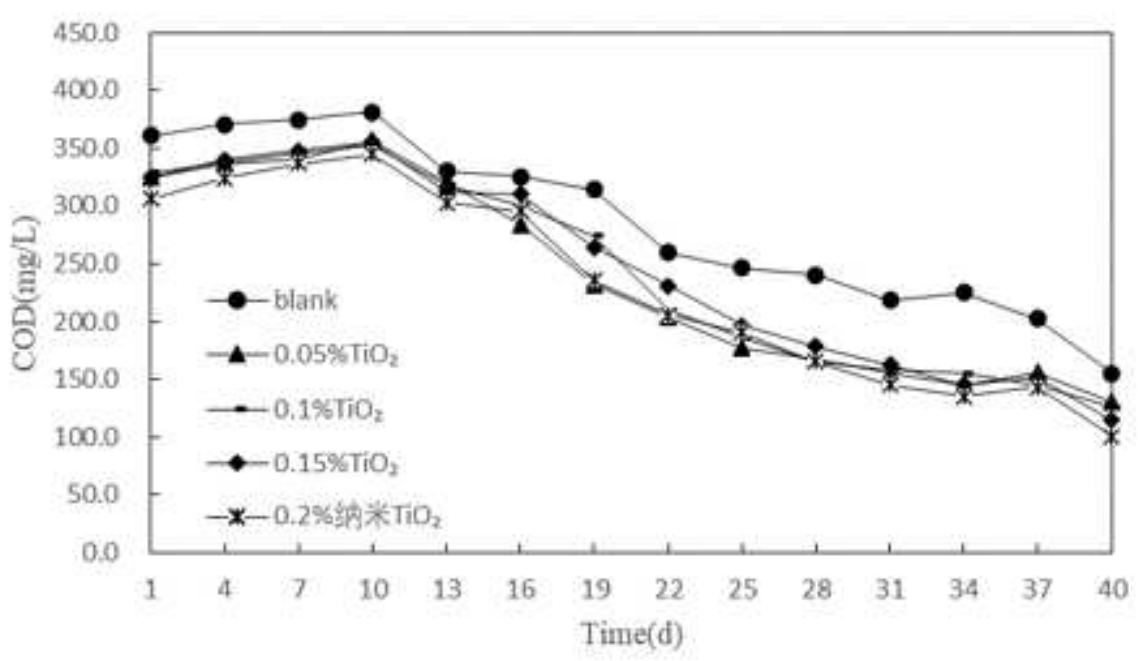

(b)

Figure 2

The curves of cumulative methane production (a) and COD (b). 


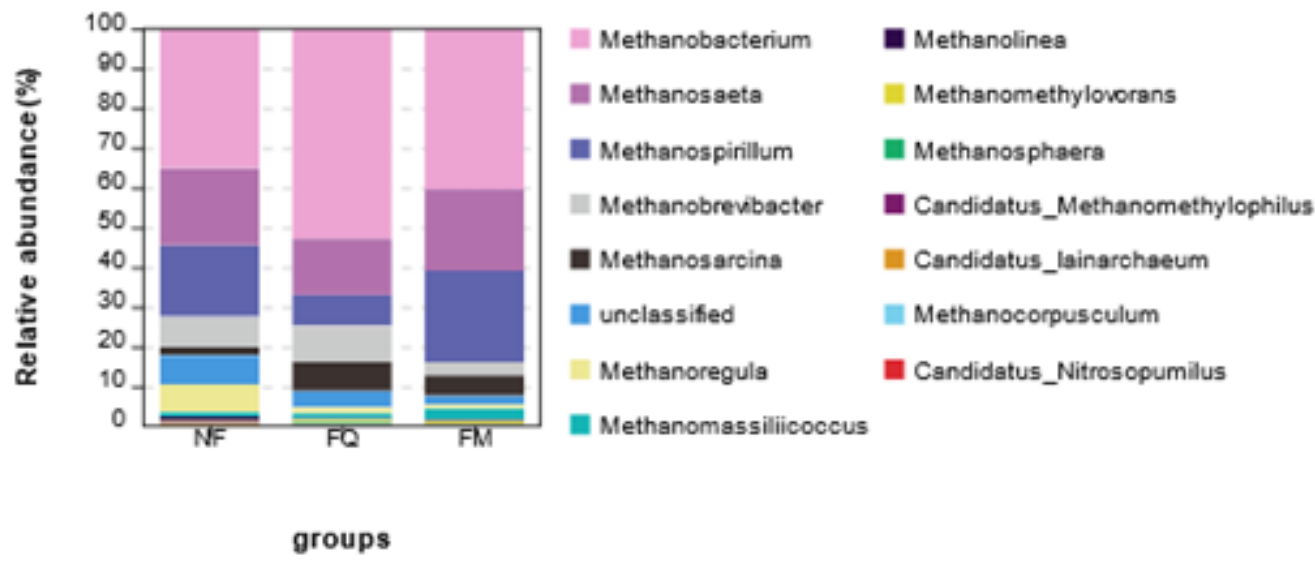

Figure 3

Distribution of various stains at the genus level during anaerobic digestion. 